\title{
A Review of the Tribe Trachodini Gistel, 1848 from Korea (Coleoptera: Curculionidae)
}

\author{
Sangwook Park ${ }^{1}, \mathrm{Ki}$-Jeong Hong* and Dongpyeo $\mathrm{Lyu}^{2}$ \\ Central Post-entry Quarantine Station, National Plant Quarantine Service, Suwon, 443-400, Republic of Korea \\ ${ }^{1}$ Seryu-dong 1167-23, Gwonseon-gu, Suwon, Gyeonggi-do, 441-881, Republic of Korea \\ ${ }^{2}$ Department of Forestry, College of Life Science \& Natural Resources, Sangji University, Wonju, 220-702, Republic of Korea
}

\section{한국산 고목바구미族의 분류학적 정리(딱정벌레목: 바구미과)}

\author{
박상욱 ${ }^{1}$ 홍기정* $\cdot$ 류동표 ${ }^{2}$ \\ 국립식물검역원 중부격리재배관리소, ${ }^{1}$ 경기도 수원시 권선구 세류동, ${ }^{2}$ 상지대학교 생명자원과학대학 산림과학과
}

\begin{abstract}
In total, 7 species of two genera under the tribe Trachodini Gistel are recognized from Korea. Among them, four species, Trachodes ovipennis Morimoto et Miyakawa, Acicnemis azumai Morimoto et Miyakawa, A. palliata Pascoe, and A. shibatai Voss are reported for the first time from Korea. A key to the tribe Trachodini, brief descriptions and illustrations of the adults are provided.
\end{abstract}

KEY WORDS : Coleoptera, Curculionidae, Trachodini, Trachodes, Acicnemis, Korea

\begin{abstract}
초 록 : 본 연구를 통해 바구미과의 Trachodes ovipennis Morimoto et Miyakawa, Acicnemis azumai Morimoto et Miyakawa, A. palliata Pascoe, A. shibatai Voss 등 4종을 우리나라에서는 처음으로 보고한다. 또한, 한국산 Trachodini 족에 대한 검색표를 작성하고 종별 특징에 대한 간단한 기술 및 형태 사진을 제시하였다.
\end{abstract}

검색어 : 딱정벌레목, 바구미과, Trachodini, Trachodes, Acicnemis, 한국

External characters of the tribe Trachodini, especially of the apterous genera with those of the Plinthini, Anchonini and Ithyporini, have been confused among the taxonomists to date. And the synonymy of the tribe Trachodini has been mixed up with the Acicnemidini. As defined by Alonso-Zarazaga \& Lyar (2002), Gistel proposed the Tracodisidae, 1848 and the Trachodini took the priority against the Blastophiladae Gistel, 1856 and Acicnémides Lacordaire, 1866. Kuschel (1987) proposed the tribe Acicnemidini, and Zherikhin et Egorov (1991) placed the tribe Acicnemidini under the subfamily Molytinae. In consequence, five genera are recognized in the Trachodini under the Molytinae: Acicnemis, Acicnemidia, Semelima, Trachodes and Karekizo, of which two genera occur in Korea. This tribe is characteristic in the mandibles, antennae, antennal scrobes, mesepimera, uncinate of tibiae, and complete separation of fore and middle pairs of coxal cavities (Morimoto

*Corresponding author. E-mail: curcul@hanmail.net 
and Miyakawa, 1995).

The purpose of this paper is to provide a key to the Korean Trachodini species with the brief descriptions and illustrations of the Korean species.

Abbreviations used for locality are as follows: GG Gyeonggi-do; GW - Gangwon-do; CN - Chungcheongnamdo; GN - Gyeongsangnam-do; JB - Jeonrabuk-do; JJ Jeju-do.

Materials are deposited in the Central Post-entry Quarantine Station of the National Plant Quarantine Service, Suwon, Korea.

\section{Taxonomic Accounts}

\section{Subfamily Molytinae Schoenherr, 1829}

\section{Tribe Trachodini Gistel, 1848}

\section{Key to the genera and species from Korea}

1. Each $6^{\text {th }}-7^{\text {th }}$ funicle segments of antenna slightly wider than long. Hind femora almost as large as or smaller than fore pair; middle and hind femora with teeth smaller than those on fore femora; tarsi with third segment truncate or shallowly concave at apical margin; scutellum minute or concealed; hind wing atrophied. . Genus Trachodes $\cdots 2$

- Each $6^{\text {th }}-7^{\text {th }}$ funicle segments of antenna longer than wide. Hind femora greater than fore and middle pairs, with triangular larger tooth, outer margin of tooth knife-edged to subapical constriction; tarsi with third segment deeply emarginate and bilobate; scutellum normal size; hind wings normal size.

Genus Acicnemis $\cdots 3$

2. Elytra oblong-ovate, 1.1-1.2 times as long as broad, pronotum rounded laterally and rapidly narrowing anteriorly to subapical constriction from middle in general or rarely almost parallel-sided; scaly vestiture conclorous chreous behind postmedian band, blackish tufts on third and fifth intervals conspicuous.

T. ovipennis

- Elytra oblong-ovate, 1.3 times as long as broad, pronotum almost straight or weakly rounded laterally; scaly vestiture behind grayish postmedian band predominantly dark brownish, blackish tufts on third and fith intervals usually smaller and often inconspicuous.

\section{T. subfasciatus}

3. Antennae with fifth and sixth segments almost as long as or 0.8-1.2 times as long as broad, club without neck at base.

\section{4}

- Antennae slender, fifth and sixth segments more than 1.5 times as long as broad, club with narrow neck at base.

A. luteomaculata

4. Hind tibiae slightly dilated internally behind the middle, inner apical corners of tibiae rounded in male. Elytra without post-median pale band. ……... A. suturalis

- Hind tibiae strongly dilated internally at apical third, inner apical corners of tibiae pointed or angulated

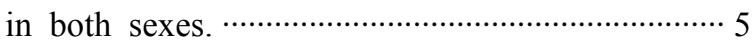

5. Elytra with first interval yellowish brown to grayish ocherous in the middle between basal black stripe and black patch on declivity in contrast to grayish brown general scaling. A. azumai

- Elytra with first interval similarly colored to the neighboring intervals in the middle. ……............. 6

6. Funicles with second segment shorter than first. Blackish V-shaped patch behind post-median white patch. Postmedian patch extending laterally to fourth interval at most. Small species A. shibatai

- Funicles with second segment slender, at least as long as first. No black patch behind post-median grayish patch. Post-median patch extending laterally to fifth interval at least. A. palliata

\section{Genus Trachodes Germar, 1824}

Trachodes Germar, 1824, Ins. Sp. Nov.: 325. (Typespecies: Curculio hispidus L.)

Metrachodes Marshall, 1948, Novit. Zool., 42: 427. Atrachodes Morimoto, 1962, J. Fac. Agr. Kyushu Univ., 11: 405.

Distribution. Korea, Japan, Far Eastern Russia, Java, India, Syria, Egypt, Caucasus, Europe, Canada (introduced). 
Trachodes (Trachodes) ovipennis Morimoto et Miyakawa, 1995 둥근날개고목바구미(신칭,Fig 1. A, H)

Trachodes (Trachodes) ovipennis Morimoto et Miyakawa, 1995, Esakia, (35): 22. (TL: Japan)

Measurements. Body length (excl. rostrum). $3.9 \mathrm{~mm}$. Adults. Derm dark brown, except for reddish brown rostrum, antennae, tarsi and ends of tibiae. Body covered with ocherous white, grayish brown and blackish brown scales. Pronotum with round blackish brown patch at middle surrounding with grayish brown scale patches. The round patch opened and pale to anterior margin. grayish brown scale patches continued to humeral angle of elytra. Elytral declivity with grayish brown scales after ocherous white band. Rostrum almost same length with pronotum. Pronotum slightly depressed longitudinally in middle and the depression obsolete at middle. Elytra 1.1-1.2 times as long as broad. Hind femur not reached to the end of elytra.

Material examined. JJ. 1 ex, Mt. Hanrasan, Eorimok, Jeju City, 27.VIII.1998.

Distribution. Korea (new record: Jeju Is.), Japan.

Remarks. This species is similar to T. subfasciatus in appearance, but can be distinguished from the latter by rather strongly rounded elytral shape.

Trachodes (Trachodes) subfasciatus Voss, 1957 무 늬고목바구미(Fig. 1. B, I)

Trachodes subfasciatus Voss, 1957, Entomol. Rev. Japan, 8: 36. (TL: Japan)

Measurements. Body length (excl. rostrum). $3.9 \mathrm{~mm}$. Adults. Derm blackish brown, except for reddish brown rostrum, antennae, tarsi and ends of tibiae. Body covered with ocherous, light brown, dark brown, and black scales. Pronotum with round and blackish brown patch at middle surrounding with grayish brown scale patches, and the round patch opened and paled to anterior margin. Apical margin of pronotum with a pair of blackish brown tufts and some brownish erected scales in each sides of the tufts. A transverse row of four tufts at a little in front of the middle of pronotum, of which the median pair blackish. Elytral declivity with light brown scales after ocherous band. Pronotum not depressed longitudinally in middle. Elytra 1.3 times as long as broad. Hind femur reached to the end of elytra.

Material examined. GB. 1ex, Mt. Sobaeksan, Yeongju City, 11-14.VI.1999.

Distribution. Korea (South, Jeju Is.), Japan, Kuriles.

Biology. Weevils were captured on dead trunks and branches of the broad-leaved trees, and often collected by shifting litter of the forest floor in Japan (Morimoto and Miyakawa, 1995)

Remarks. This species is similar to the proceeding, but has slightly narrowed and parallel sides of elytra.

\section{Genus Acicnemis Fairmaire, 1849}

Acicnemis Fairmaire, 1849, Rev. Mag. Zool., 1849: 511 (rep.: 63)(Type-species: Acicnemis variegates Fairmaire, 1849, monobasic).

Berethia Pascoe, 1872, J. Linn. Soc. Lond., XI: 463

(Described on Berethia medinotata Pascoe and sannio Pascoe).

Distribution. Korea, Japan, China, Far Eastern Russia, Oriental Region, Australia, New Guinea, Samoa.

Acicnemis azumai Morimoto et Miyakawa, 1995 자 귀나무고목바구미(신칭, Fig 1. C, J)

Acicnemis azumai Morimoto et Miyakawa, 1995, Esakia 35: 40 (TL: Japan: Okinawa)

Measurements. Body length (excl. rostrum). 3.8-4.7 $\mathrm{mm}$.

Adults. Body reddish brown; scaling dense with short white and black stripes and long grayish patches. Dorsum with somewhat long suberect scale, especially odd number of intervals on elytra. Basal part of $3^{\text {rd }}$ intervals of elytra with whitish scales. Suberect scales on underside of body and legs somewhat short and pale. Rostrum slightly narrowing anteriorly, and then weakly widening at apical area; antennae inserted in the basal two forth in male or more closely inserted to the base in female. Pronotum broadest just before the middle, thence scarcely narrowing posteriorly, disk with dense punctures, shortly keeled at the sides of one or two pairs of punctures in 


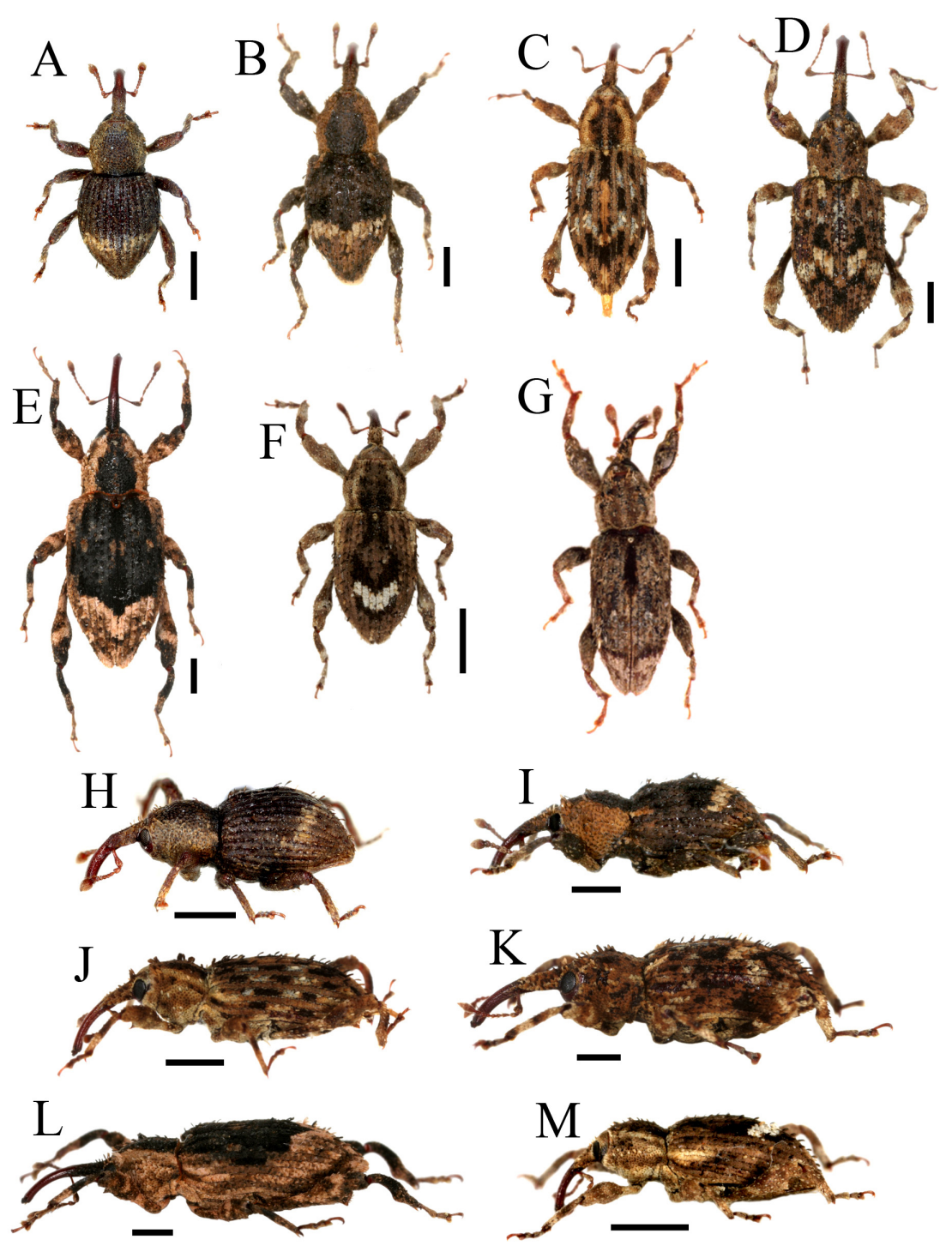

Fig. 1. Habitus of Adults. - A, H: T. ovipennis, B, I: T. subfasciatus, C, J: A. azumai, D, K: A. luteomaculata, E, L: A. palliata, F, M: A. shibatai, G: A. suturalis (G: Morimoto et Miyakawa, 1995). Scale bars $=1.0 \mathrm{~mm}$.

front of scutellum. Scutellum ovate. Elytra almost parallelsided on basal 3/5, subapical calli weak. Segment between $1^{\text {st }}$ and $2^{\text {nd }}$ ventrites obscure at middle. $1^{\text {st }}$ and $2^{\text {nd }}$ ventrites long, $3^{\text {rd }}$ and $4^{\text {th }}$ short, $5^{\text {th }}$ almost as long as $3^{\text {rd }}$ and $4^{\text {th }}$ combined. Legs slender, femora clavate with sharp tooth. Hind femora almost reach to apex of elytra, widening apically from the middle. Hind tibiae dilated internally at apical third.

Material examined. GW. 2exs, Hoengseong, 10.VI.2007; CN. 1ex, Donamri, Banpomyeon, Gongju City, 19-26. VII.2005; JJ. 1ex, Sinheung, Namjeju, 23.IX.1998; JJ. 1ex, Jeolmul, Donggyedong, Jeju City, 10-16.IX.2005; JJ. 1ex, Jeolmul, Donggyedong, Jeju City, 21-27. VI. 2007.

Distribution. Korea (new record: Middle, Jeju Is.), Japan. Remarks. A specimens was captured on Albizzia sp. at late of September in Jeju Island. Other specimens was collected with malaise trap or by sweeping the bushes.

Acicnemis luteomaculata Morimoto et Miyakawa, 1995 제주고목바구미(Fig 1. D, K)

Acicnemis luteomaculata Morimoto et Miyakawa, 1995, 
Esakia, 35: 39. (Japan; Fukuoka)

Measurements. Body length (excl. rostrum). $5.0 \mathrm{~mm}$. Adults. Derm blackish brown except for reddish brown antennae, rostrum, unci of tibiae and tarsi; scaling similiatr to A. azumai. Elytra with a pair of whitish patch on basal area of third intervals, a whitish M-shaped wide patch on sub-apical area apart by $1^{\text {st }}$ intervals and a blackish M-shaped patch. Rostrum slightly narrowing anteriorly, then weakly widening at apical area; male antennae inserted just behind the middle. Pronotum broadest around the middle, almost parallel-sided posteriorly, not keeled just before the scutellum. Scutellum oblong, with grayish brown scales. Elytra 1.5 times as long as broad, parallelsided on basal half, second and third intervals widened around the middle, much broader than striae. $1^{\text {st }}$ and $2^{\text {nd }}$ ventrites long, $3^{\text {rd }}$ and $4^{\text {th }}$ short, $5^{\text {th }}$ almost as long as $3^{\text {rd }}$ and $4^{\text {th }}$ combined. Legs slender, femora with sharp tooth, stalk of hind femora as long as the club, dilated internally at middle.

Material examined. JJ. 1ex, Kwaneumsa, Jeju City, 15.VII.1997.

Distribution. Korea (Jeju Is.), Japan.

Remarks. This species very similar to A. azumai, but easily distinguish from the latter by following characters. Antennal funicles loosely articulated, not short. Basal part of $3^{\text {rd }}$ intervals of elytra with whitish scale patches. Hind femoral tooth almost same size of others, but those of A. azumai much bigger than fore and mid femoral teeth.

\section{Acicnemis palliata Pascoe, 1872 등나무고목바구미} (신칭, Fig 1. $\mathrm{E}, \mathrm{L}$ )

Acicnemis palliata Pascoe, 1872, J. Linn. Soc. Lond., 11: 462. (TL: Japan)

Measurements. Body length (excl. rostrum). 4.8-7.0 mm. Adults. Derm blackish brown, except for dark reddish brown antennae, rostrum and tarsi, with dense scales and brownish grey and blackish patches. Middle of pronotum and elytra with blackish patch on dorsal area. Underside and legs almost brownish grey except a pair of blackish patches on second ventrite. Apical area of femora and basal area of tibiae black. Rostrum somewhat slender, antennae inserted in $2 / 5$ of rostrum from base. Punctures of rostrum minute except basal 2/5. Pronotum 1.05-1.08 times as broad as long, almost parallel-sided on basal half, with dens punctures. Scutellum tongue-shaped. Elytra 1.8 times as long as broad, parallel-sided on basal 3/5, intervals flat, much broader than striae. $1^{\text {st }}$ and $2^{\text {nd }}$ ventrites long, $2^{\text {nd }}$ almost as long as $3^{\text {rd }}-5^{\text {th }}$ combined. Hind femoral tooth greater than fore and mid femoral teeth. Hind tibiae strongly expanded internally at apical third.

Material examined. GG. 19exs, Mangpodong, Suwon City, 24.VIII.2003; ditto, 2exs, 16.IX.2003; ditto, 19exs, 1.V.2007; 4exs, Mt. Soyosan, Dongducheon City, 26.V. 2004; GN. 21exs, Nopodong, Busan City, 28.VI.2006.

Distribution. Korea (new record: Middle, South), Japan (Honshu, Shikoku, Kyushu, Tsushima), China(?).

Acicnemis shibatai Voss, 1971 애고목바구미(신칭, Fig. 1. $\mathrm{F}, \mathrm{M})$

Acicnemis shibatai Voss, 1971, Mem. Fac. Educ., Kagawa Univ., II(202): 52. (TL: Japan)

Measurements. Body length (excl. rostrum). $3.0-3.6 \mathrm{~mm}$ Adults. Derm reddish brown with ash-colored, pale black, and white scales. Ashed oval patch in the middle surrounded with blackish patch and characteristic by V-shaped white postmedian patch on elytra. Hind femur not reached to the end of elytra.

Material examined. GG. 3exs, Hwadoeub, Namyangju City, 27.V.2007; 1ex, Dongbaekri, Guseongeub, Yongin City, 27.VI-9.VII. 2007; 1ex, Arb. Kwanag, Manangu, Anyang City, 31.V-13.VI.2008; 1ex, Mt. Taehwa, Docheokmyoen, Gwangju City, 9-24.VI.2007; 1ex, Mt. Taehwa, Docheokmyoen, Gwangju City, 15-25.VII.2008; CN. 1ex, Ibjangmyeon, Cheonan City, 1.VI, 2008.

Distribution. Korea (new record: Middle), Japan, Taiwan.

Remarks. Most specimens was collected with malaise trap or by sweeping the bushes.

Acicnemis suturalis Roelofs, 1875 등고목바구미(Fig. 1. G)

Acicnemis suturalis Roelofs, 1875, Ann. Soc. ent. Belg., XVIII: 154. (TL: Japan) 
Measurements. Body length (excl. rostrum). $3.8 \mathrm{~mm}$. Adults. Derm blackish brown except for dark reddish brown antennae and tarsi; scaling dense, patch somewhat simple. pronotum pale brown with dark brown stripe-type patches. Antennae robust, club without neck. Pronotum slightly longer than wide, broadest at the middle. elytra predominantly dark brownish to brownish black, with whitish post-median patches absent or small and indefinite on second and third intervals if present, with distinct grayish transverse band in entire width, which produced posteriorly on median intervals and fringed transversely along anterior margin with blackish band, velvety black stripe distinct on basal third of first interval, similar but narrower velvety stripes often present on the base of fifth interval and also on third interval in the middle. Tibiae slightly dilated internally behind the middle. Underside grayish, often with dark spot on each side of second and fifth ventrites.

Distribution. Korea (Jeju Is.), Japan, China, Taiwan.

Remarks. Weevils were found on dead vine of Wistaria brachybotrys in Japan (Morimoto and Miyakawa, 1995). The first record from Korea was done from Jeju Is. by Morimoto and Lee (1992). Hong et al. (2000) added a record of this species with a specimen from Mt. Naejangsan, Jeonrabuk-do, but the specimen used in this record quite differ to A. suturalis as follow reasons. First, A. suturalis has the length ratio of antennal funicle and club as 68:49 (Morimoto and Miyakawa, 1995), but the specimen described by Hong et al. has the ratio about 68:26. Because of the lost of the specimen used by Hong et al., we couldn't measure the ratio with the specimen directly. But we could estimate the ratio with the photo in the plate. Second, Hong et al.'s specimen has an ocherous patch on the basal margin of pronotum before the scutellum, but $A$. suturalis doesn't have. Last, $A$. suturalis has somewhat robust hind femur and weakly dilated tibia, but Hong et al.'s specimen has somewhat long femur and strongly dilated tibia. So, we conclude that the record in Mt. Naejangsan, Jeonrabuk-do is invalid.

\section{Acknowledgment}

This work was supported financially by the National Project of the Biological Collections in the Korean peninsula, Korea National Arboretum, Korea.

\section{Literature Cited}

Alonso-Zarazaga, M.A. and C.H.C. Lyal. 1999. A World Catalogue of Families and Genera of Curculionoidea (Insecta: Coleoptera). 315pp. Entomopraxis, Barcelona.

Alonso-Zarazaga, M.A. and C.H.C. Lyal. 2002. Addenda and corrigenda to 'A World Catalogue of Families and Genera of Curculionoidea (Insecta: Coleoptera)'. Zootaxa, 63: 31-32.

Hong, K.J., A.B. Egorov and B.A. Korotyaev. 2000. Illustrated Catalogue of Curculionidae in Korea (Coleoptera). Insects of Korea, 5: 1-340.

Hong, K.J. and B.A. Korotyaev. 2002. On Some Species of Curculionidae (Coleoptera) from North Korea. Korean Journal of Applied Entomology, 41(3): 151-169.

Kojima, H and K. Morimoto. 2004. An Online Checklist and Database of the Japanese Weevils (Insecta: Coleoptera: Curculionoidea) (excepting Scolytidae and Platypodidae). Bull. Kyushu Univ. Museum. 2: 33-147.

Morimoto K. and C. E. Lee. 1992. Curculionidae from Cheju Island, Korea, with Descriptions of Three New Species (Insecta, Coleoptera). Esakia, (32): 1-18.

Morimoto K. and S. Miyakawa. 1995. The Family Curculionidae of Japan. VIII. Subfamily Acicnemidinae. Esakia, (35): 17-62.

Morimoto K. 2001. Notes on the Weevil Genus Trachodes in Japan (Coleoptera: Curculionidae: Acicnemidini). Spec. Publ. Japan Coleopt. Coc., Osaka, (1): 287-292.

Roelofs, W. 1875. Curculionidae recueillis au Japon par M.G. Lewis (3e). Ann. Soc. Ent. Belg., 16: 149-193, pl.II.

The Entomological Society of Korea and Korean Society of Applied Entomology (ESK/KSAE). 1994. Family Curculionidae. p. 202-210. In Check List of Insects from Korea. 744pp. KonKuk Univ. Press, Seoul.

Zherikhin, V.V. and Egorov, A.B. 1991. Zhuki-dolgonoiski (Coleoptera, Curculionidae) dal'nego vostoka SSSR (obzor podsemejstv s opisaniem novykhtaksonov). 164pp. Akademija Nauk SSSR, Dal'nevostochnoe Otdelenie, Biologo-Pochvennyj Institut. Vladivostok.

(Received for publication January 28 2009;

revised March 5 2009; accepted March 7 2009) 